\title{
Antiviral therapy against chronic hepatitis B in Brazil: high rates of lamivudine resistance mutations and correlation with HBV genotypes
}

\author{
Francisco Campello do Amaral Mello', Carlos Augusto Fernandes², Selma de Andrade Gomes ${ }^{1 /+}$ \\ 'Laboratório de Virologia Molecular, Instituto Oswaldo Cruz-Fiocruz, Av. Brazil 4365, 21045-900 Rio de Janeiro, RJ, Brasil \\ ${ }^{2}$ Laboratório Central de Saúde Pública Noel Nutels, Rio de Janeiro, RJ, Brasil
}

\begin{abstract}
The effectiveness of antiviral treatments of chronic hepatitis B has been poorly studied in Brazil. Here, hepatitis $B$ virus (HBV) DNA positivity, drug resistance mutations and their association with $H B V$ genotypes were evaluated in chronically $H B V$-infected patients under different drug regimens in Brazil. The study involved 129 patients under interferon or nucleos(t)ide analogue therapy for a median treatment time of 12 months. One hundred and five (81\%) of these patients were treated with lamivudine (LAM), either in monotherapy or in combination with newer drugs, such as entecavir (ETV) or tenofovir (TDF). High (37.5-100\%) rates of HBV DNA positivity were observed with all but one drug regimen $(L A M+E T V)$. However, patients that were treated with ETV alone, TDF alone or with LAM combination therapies had a mean viral load that was 3-4 log lower than patients treated with LAM monotherapy. Of the patients treated with LAM, 47\% developed resistance mutations. HBV genotypes A (59.1\%), D (30.3\%) and $F(9.1 \%)$ were found. There was no association between the presence of LAM resistance mutations and genotypes, HBeAg status or treatment duration. Nevertheless, the rtM204V mutation was observed more frequently (12/13, 92\%) in genotype A than in the others $(p=0.023)$. Six out of nine isolates that contained the rtM204I mutation belonged to genotype $D$ and half of them displayed a single mutation. Genotype D isolates with the rtM204V variant preferentially displayed a triple mutation, while genotype A preferentially displayed a double mutation $(p=0.04)$.
\end{abstract}

Key words: HBV - therapy - lamivudine - antiviral drug resistance

Hepatitis B virus (HBV) infection constitutes a major problem of public health. An estimated 350 million people worldwide are chronically infected with HBV and are thus exposed to a progressive disease that may lead to liver cirrhosis and hepatocellular carcinoma (HCC) (WHO 2008, Wiegand et al. 2010). Advances in the antiviral therapy against chronic hepatitis B occurred during the last decade, as nucleos(t)ide analogue (NA) drugs were developed. These drugs provided a treatment option other than interferon-alpha (IFN- $\alpha$ ). Today, seven drugs are licenced in the United States for the treatment of HBV infection: IFN- $\alpha$, pegylated IFN- $\alpha$, lamivudine (LAM), adefovir (ADV), entecavir (ETV), telbivudine (LdT) and tenofovir (TDF) (Dienstag 2008).

The ultimate goals of antiviral therapy are clinical and histological improvement, including a decrease in the necroinflammatory grade, which consequently reduces the risk of cirrhosis and HCC. Thus, the following surrogate markers are used to measure these goals: reduced HBV replication (decrease or suppression of HBV DNA to undetectable levels), anti-HBe seroconversion and normalisation of alanine aminotransferase (ALT) levels (Bhattacharya \& Thio 2010). Although antiviral therapy with NAs is efficient for reducing or suppressing HBV replication in most patients, its long-term use can

+ Corresponding author: selma@ioc.fiocruz.br

Received 30 May 2011

Accepted 8 November 2011 lead to the selection of drug-resistant viruses. This drug resistance alters the ability of the drug to control viral replication and thus is normally followed by an increase in viral load (VL) and ALT levels as well as progression of liver disease (Svicher et al. 2009, Zoulim \& Locarnini 2009). Mutations in the reverse transcriptase (rt) domain of the HBV polymerase gene, particularly in the YMDD motif at rt204 (rtM204V/I), allow the viruses to become resistant to LAM and LdT treatments. The occurrence of this mutation in combination with another substitution in the rt domain (rt184, rt202, or rt250) causes resistance to ETV (Enomoto et al. 2007). This cross-resistance and multi-drug resistance further complicates the treatment of chronic hepatitis B with NAs. Because primary LAM resistance mutations rtM204V/I can compromise viral replication fitness, compensatory mutations in the $\mathrm{rt}$ domain (rtL180M, rtV173L, rtL80I/V) that partially restore replication efficiency are often co-selected in HBV rt204 mutants (Yuen \& Locarnini 2009). LAM, the first NA drug licenced for the treatment of chronic hepatitis B and still in widespread use, has major drawbacks, including a high incidence of virological relapse when treatment is discontinued and the highest rate of resistance. The drug resistance progressively increases over the course of the treatment and is found in $80 \%$ of patients after 48 months of administration (Dienstag et al. 1999, Lai et al. 2003, Zoulim \& Locarnini 2009). Lower rates of resistance were reported in patients treated with other NAs. For instance, resistance rates to ADV reached $29 \%$ after five years (Hadziyannis et al. 2006), while resistance to ETV had rates of $1.2 \%$ and $51 \%$ after five years in NA naïve-patients and the LAM-resistant population, respectively. In addition, resistance to LdT was 
reported in $21 \%$ of the patients after two years of therapy. On the other hand, no virological resistance to TDF has been observed thus far (Delaney \& Borroto-Esoda 2008). Available data indicate that the best treatment for patients with LAM resistance is to continue LAM and add on ADV or TDF (Zoulim \& Locarnini 2009). ETV is not an optimal treatment for LAM-resistant infections due to cross-resistance between these drugs. If ETV is chosen as rescue therapy, LAM treatment should be discontinued (Zoulim \& Locarnini 2009).

As stated in the latest Clinical Protocol and Therapeutic Guidelines for the Treatment of Chronic Hepatitis B and Co-infections, which was released by the Brazilian Ministry of Health in 2010, the absence of an universal therapeutic guideline for the treatment of chronic hepatitis B in Brazil during previous years has led to a need for different therapies among the states of the Federation (MS 2010). The current protocol has established national guidelines for the treatment of chronic hepatitis $\mathrm{B}$ that incorporates ADV, ETV and TDF as antiviral drugs provided by the government in addition to IFN- $\alpha$ and LAM.

Lately, several aspects of HBV have been under investigation: genetic variability and the effects on the occurrence of mutations, clinical outcome and severity of liver disease and the response to antiviral therapy (Kramvis \& Kew 2005, Cao 2009, Yuen \& Locarnini 2009). Through a systematic review of the literature, the patterns of LAM resistance mutations associated with HBV genotypes, specifically genotypes A-D, have also been studied (Damerow et al. 2010).

As the effectiveness of antiviral treatments against chronic hepatitis B in Brazil has been poorly studied, the aims of the present study were to evaluate the overall efficiency of each therapy in reducing HBV DNA levels, the frequency of drug-resistant isolates and to establish an association of the type of mutation with the HBV genotypes that are circulating in Brazil.

\section{SUBJECTS, MATERIALS AND METHODS}

Study population - This cross-sectional study involved $129 \mathrm{HBsAg}$-positive serum samples collected between 2008-2009 from chronically infected HBV patients undergoing different HBV drug therapies. These samples were referred to a public Brazilian central laboratory [Noel Nutels Laboratory in Rio de Janeiro (RJ)] for the assessment of HBV loads and came from different Brazilian states [RJ, Espírito Santo (ES), Minas Gerais (MG) and Santa Catarina (SC)]. Serum samples were taken from patients within the Brazilian territory who were treated with different therapeutic strategies during distinct periods of time. The different strategies were as follows: (i) IFN- $\alpha$, (ii) LAM monotherapy, (iii) LAM + TDF, (iv) LAM + ADV, (v) LAM + ETV, (vi) ETV-monotherapy, (vii) ADV-monotherapy and (viii) TDF-monotherapy. Medical records were reviewed to determine demographic (gender, age and locality), clinical (ALT level as well as type and duration of treatment) and serological (HBeAg status) characteristics of the patients. According to the latest Clinical Protocol and Therapeutic Guidelines for the Treatment of Chronic Hepatitis B and Co-infections (MS 2010), HBV VL of patients under antiviral treatment should be monitored every six months depending on their biochemical and serological status. The local Ethical Committee approved the protocol for this study.

Viral DNA extraction and polymerase chain reaction $(P C R)$ amplification - HBV DNA was extracted from serum samples using the High Pure Viral Nucleic Acid Kit (Roche Applied Science, Mannheim, Germany), according to the manufacturer's instructions. Viral DNA was eluted in $50 \mu \mathrm{L}$ of elution buffer.

The pre-S/S genome region was amplified by seminested PCR. The first round PCR product was amplified with primer pairs PS1 (5'-CCATATTCTTGGGAACAAGA-3', nt positions 2826-2845) and P3 (5'-AAAGCCCAAAAGACCCACAA-3', 1000-1019). The second round was performed with sense primer PS1 and two antisense primers, S2 (5'-GGGTTTAAATGTATACCCAAAGA-3', nt 819-841) and S22 (5'-GTATTTAAATGGATACCCACAGA-3', nt 819-841), which were located at the same position on the genome to facilitate the amplification of all HBV genotypes (Moraes et al. 1999). DNA was amplified using $5 \mathrm{U} / \mu \mathrm{L}$ Taq DNA polymerase (Invitrogen, San Diego, CA, USA), $10 \mathrm{mM}$ dNTPs, 10X PCR buffer, $50 \mathrm{mM} \mathrm{MgCl}$ and $10 \mu \mathrm{M}$ primer mix in a final volume of $50 \mu \mathrm{L}$. The DNA amplification was then performed under the following conditions: one cycle at $94^{\circ} \mathrm{C}$ for $3 \mathrm{~min}, 30$ cycles of $94^{\circ} \mathrm{C}$ for $30 \mathrm{~s}, 55^{\circ} \mathrm{C}$ for $30 \mathrm{~s}$ and $72^{\circ} \mathrm{C}$ for $1 \mathrm{~min}$ $30 \mathrm{~s}$, followed by a final elongation step $\left(7 \mathrm{~min}\right.$ at $\left.72^{\circ} \mathrm{C}\right)$ for the first round. For the second round, the PCR was performed for one cycle at $94^{\circ} \mathrm{C}$ for $3 \mathrm{~min}, 30$ cycles of $95^{\circ} \mathrm{C}$ for $30 \mathrm{~s}, 52^{\circ} \mathrm{C}$ for $10 \mathrm{~s}$ and $72^{\circ} \mathrm{C}$ for $2 \mathrm{~min}$, followed by a final elongation step $\left(7 \mathrm{~min}\right.$ at $\left.72^{\circ} \mathrm{C}\right)$. The lower limit of detection of the PCR assay was 100 copies $/ \mathrm{mL}$.

Nucleotide sequencing, genotyping and mutational analysis - PCR products were purified using the Wizard SV Gel and PCR Clean-Up System (Promega, Madison, USA) and prepared for sequencing using a Large Dye Terminator 3.1 Cycle Sequencing Kit (Applied Biosystems, Foster City, CA, USA) with external primers PS1 and S2 or S22, the internal sense primer S4 (5'-TGCTGCTATGCCTCATCTTCT-3', nt 416-436) and the antisense primer S7 (5'-TGAGCCAGGAGAAACGGGCT-3', nt 676-656). The sequence was then determined by separation and analysis of extension products using an automated ABI 3730 DNA Analyzer (Applied Biosystems). All sequences determined in this study have been deposited in the GenBank database (accessions JF784214-JF784278).

HBV genotyping was performed by phylogenetic analysis of the pre-S/S gene of the sequences determined in this study compared with HBV sequences representing all known genotypes available in the GenBank. Sequences were aligned using the CLUSTALW programme (Thompson et al. 1994) and a phylogenetic-tree was generated using the neighbour-joining method (bootstrap resampling test with 1,000 replicates) using the MEGA version 4.0 software (Tamura et al. 2007).

Drug-resistant mutations were analysed in the deduced amino acid (aa) sequence of the ORF P, which overlapped with the pre-S/S gene and covered the rt domain from aa 1-230. 
Quantification of HBV DNA by real-time (RT-PCR) - HBV DNA-positive samples were quantified using the RT-PCR TaqMan technology, according to Pas and Niesters (2002), with some modifications. A panel of serial dilutions of a plasmid with a known amount of HBV DNA molecules was used for quantification by RT-PCR. Amplification assays were performed in a final volume of $25 \mu \mathrm{L}$ of TaqMan universal Master Mix (Applied Biosystems), containing $5 \mu \mathrm{L}$ of DNA, $1 \mu \mathrm{M}$ of the primers S14 (sense, 5'-GGACCCCTGCTCGTGTTACA-3', nt 184-203) and S17 (antisense, 5'-AGAGAAGTCCACCMCGAGTCTAGA-3', nt 273-249) and 0.3 $\mu \mathrm{M}$ of the probe HBV-3 (5'-FAM-TGTTGACAARAATCCTCACAATACCRCAGA-TAMRA-3', nt 218-247). After the initial incubation steps at $50^{\circ} \mathrm{C}$ for $2 \mathrm{~min}$ and $95^{\circ} \mathrm{C}$ for $10 \mathrm{~min}$, the PCR cycling programme consisted of 50 cycles at $95^{\circ} \mathrm{C}$ for $15 \mathrm{~s}$, followed by $60^{\circ} \mathrm{C}$ for $60 \mathrm{~s}$. Reactions were performed in an ABI PRISM 7700 SDS system (Applied Biosystems). The assay had a limit of detection of 10 copies/reaction or approximately 100 copies $/ \mathrm{mL}$ of serum.
Statistical analysis - Categorical variables were compared using the Pearson $\chi^{2}$ or Fisher's exact tests when relevant and differences between the continuous variables were assessed by Student's $t$ test and the Mann-Whitney U test, when required. Differences were considered statistically significant when the $p$ value less than 0.05 . All statistical analyses were performed using SPSS version 17 (SPSS, Chicago, IL).

\section{RESULTS}

Demographic, clinical and virological features - In total, 129 HBsAg-positive chronically infected patients who were enrolled in this study were under HBV drug treatment with IFN- $\alpha$ or NAs (Table I). Most patients were male $(79.8 \%)$ with a median age of 45 years and were located in ES (37.2\%). In total, 66 patients (51.2\%) had detectable HBV DNA in serum. No statistically significant differences were found for HBV DNA positivity related to gender, age, geographic locality, the type of treatment or duration of the treatment (Table I). Elevated

\section{TABLE I}

Patients' demographic, clinical and virological characteristics associated with the detection of hepatitis B virus (HBV) DNA

\begin{tabular}{|c|c|c|c|c|}
\hline & Total & HBV DNA+ & HBV DNA- & $\mathrm{p}^{a}$ \\
\hline Patients [n (\%)] & 129 & $66(51.2)$ & $63(48.8)$ & - \\
\hline \multicolumn{5}{|l|}{ Gender [n (\%)] } \\
\hline Female & $26(20.2)$ & $16(61.5)$ & $10(38.5)$ & NS \\
\hline Male & $103(79.8)$ & $50(48.5)$ & $53(51.5)$ & - \\
\hline \multicolumn{5}{|l|}{ Age (years) } \\
\hline Mean & $44.9 \pm 11.4($ range $16-76)$ & $44.2 \pm 11.3($ range $19-76)$ & $45.7 \pm 11.6($ range $16-71)$ & NS \\
\hline Median & 45 & 45 & 45 & - \\
\hline \multicolumn{5}{|l|}{ Locality [n (\%)] } \\
\hline Espírito Santo & $48(37.2)$ & $21(43.8)$ & $27(56.2)$ & NS \\
\hline Minas Gerais & $40(31)$ & $20(50)$ & $20(50)$ & - \\
\hline Rio de Janeiro & $25(19.4)$ & $10(40)$ & $15(60)$ & - \\
\hline Santa Catarina & $16(12.4)$ & $6(37.5)$ & $10(62.5)$ & - \\
\hline \multicolumn{5}{|l|}{ ALT levels [n (\%)] } \\
\hline Normal & $69(53.5)$ & $25(36.2)$ & $44(68.8)$ & $<0.01$ \\
\hline Elevated & $53(41.1)$ & $38(71.7)$ & $15(28.3)$ & - \\
\hline Not done & $7(5.4)$ & $3(42.9)$ & $4(57.1)$ & - \\
\hline \multicolumn{5}{|l|}{ HBeAg [n (\%)] } \\
\hline Negative & $60(46.5)$ & $25(41.6)$ & $35(58.3)$ & 0.03 \\
\hline Positive & $62(48.1)$ & $38(61.3)$ & $24(38.7)$ & - \\
\hline Not done & $7(5.4)$ & $3(42.9)$ & $4(57.1)$ & - \\
\hline \multicolumn{5}{|l|}{ Treatment [n (\%)] } \\
\hline LAM & $86(66.7)$ & $42(48.8)$ & $44(51.2)$ & NS \\
\hline Combined therapy $^{b}$ & $19(14.7)$ & $8(42.1)$ & $11(57.9)$ & - \\
\hline ETV & $13(10.1)$ & $6(46.1)$ & $7(53.9)$ & - \\
\hline IFN- $\alpha$ & $8(6.2)$ & $8(100)$ & $0(0)$ & - \\
\hline ADV & $2(1.5)$ & $1(50)$ & $1(50)$ & - \\
\hline TDF & $1(0.8)$ & $1(100)$ & $0(0)$ & - \\
\hline \multicolumn{5}{|c|}{ Treatment time (months) } \\
\hline Mean & $20.4 \pm 2.0$ & $21.1 \pm 3.1$ & $19.7 \pm 2.0$ & NS \\
\hline Median & 12 & 12 & 12 & - \\
\hline
\end{tabular}

$a$ : Pearson chi-square, 95\% confidence limits; $b$ : combined therapy [lamivudine (LAM) + tenofovir (TDF); LAM + adefovir (ADV); LAM + entecavir (ETV)]; ALT: alanine aminotransferase; IFN- $\alpha$ : interferon-alpha; NS: not significant. 
ALT levels $(\mathrm{p}=0.0001)$ and HBeAg positivity $(\mathrm{p}=0.03)$ were significantly associated with HBV DNA positivity (Table I). Comparison of HBeAg status showed that HBeAg-positive patients had higher rates of ALT levels than HBeAg-negative patients $(\mathrm{p}=0.019)$. Additionally, $\mathrm{VL}$ was significantly higher in $\mathrm{HBeAg}$-positive subjects $(\mathrm{p}=0.001)$ (data not shown).

Serological and virological data of the different therapeutic approaches - Most of the patients (86/129; $66.7 \%$ ) were treated with LAM monotherapy (Table II). LAM therapy combined with TDF, ADV and ETV was used in nine, eight and two patients, respectively. ETV monotherapy was used in $13(10.1 \%)$ patients, ADV monotherapy in two patients and TDF monotherapy in a single patient, while IFN- $\alpha$ was used in eight (6.2\%) individuals (Tables I, II). A comparison of the frequency of HBV DNA positivity, ALT levels, HBeAg status and VLs between the different treatments is shown in Table II. Most of the patients $(6 / 8 ; 75 \%)$ treated with IFN- $\alpha$ for a median time of six months had elevated ALT levels and were $\mathrm{HBeAg}$-positive. All of them had detectable levels of HBV DNA and high VL, with a mean of $7.9 \times 10^{7}$ copies $/ m L$. Except for patients treated with LAM + ETV, in which the two available samples were negative for HBV DNA, high rates $(37.5-100 \%)$ of HBV DNA positivity were observed in patients treated with the other drug regimens. However, patients that underwent treatment with more recent drugs, such as monotherapy with ETV or TDF or LAM combined therapies, had a mean VL that was 3-4 log lower than patients treated with LAM monotherapy or IFN- $\alpha$. The only patient treated with TDF monotherapy had normal ALT levels and a low VL (the lowest when compared with other therapies), despite the patient's positive serology for $\mathrm{HBeAg}$.

$H B V$ genotypes and drug-resistance mutations HBV genotypes were determined for all 66 HBV DNA positive serum samples. As expected, genotype A was the most prevalent $(39 / 66 ; 59.1 \%)$, followed by genotype D $(20 / 66 ; 30.3 \%)$ and genotype F (6/66; 9.1\%). One sample was classified as genotype B. In MG and RJ, in the southeastern region of Brazil, 80-90\% of the isolates were from genotype A. However, in ES, another state of the same geographical region, an equal distribution of genotypes A and D was found, with a frequency of $43 \%$ for both. As expected, genotype D was the most prevalent $(90 \%)$ in the south of Brazil (SC). No statistically significant association could be established between the different genotypes and the ALT levels, HBeAg status, or VL, irrespective of the treatment given to patients. Of the 39 genotype A isolates, 32 (82\%) were classified in subgenotype A1 and seven (18\%) were in subgenotype A2. Among the 20 samples classified as genotype D, $15(75 \%)$ were clustered in subgenotype D3 and the remaining five $(25 \%)$ were $\mathrm{D} 2$. The six genotype $\mathrm{F}$ isolates were classified in the subgenotypes F2 $(5 / 6 ; 83.3 \%)$ and F1b (1/6; 16.7\%). The only genotype B isolate found was from genotype B2 (data not shown).

Analysis of the deduced aa sequences of the HBV rt domain, which covers aa 1-230, showed that of the 27/50 (54\%) patients treated with LAM (in monotherapy or in combination with other NA drugs) were infected with isolates contained mutations for drug resistance. None of the patients treated with ETV, ADV or TDF alone had drug-resistant isolates. High rates of LAM-resistant

TABLE II

Virological and serological data in different therapeutic approaches

\begin{tabular}{|c|c|c|c|c|c|c|c|c|}
\hline & \multicolumn{8}{|c|}{ Hepatitis B virus (HBV) antiviral treatment } \\
\hline & IFN- $\alpha$ & LAM & $\mathrm{LAM}+\mathrm{TDF}$ & $\mathrm{LAM}+\mathrm{ADV}$ & $\mathrm{LAM}+\mathrm{ETV}$ & ETV & ADV & TDF \\
\hline Patients (n) & 8 & 86 & 9 & 8 & 2 & 13 & 2 & 1 \\
\hline \multicolumn{9}{|l|}{ ALT levels [n (\%)] } \\
\hline Normal & $2(25)$ & $45(52.4)$ & $5(55.6)$ & $5(62.5)$ & $2(100)$ & $7(53.8)$ & $2(100)$ & $1(100)$ \\
\hline Elevated & $6(75)$ & $37(43)$ & $4(44.4)$ & $2(25)$ & - & $4(30.8)$ & - & - \\
\hline $\mathrm{HBeAg}+[\mathrm{n}(\%)]$ & $7(87.5)$ & $37(43)$ & $4(44.4)$ & $5(62.2)$ & $1(50)$ & $6(46.1)$ & $1(50)$ & $1(100)$ \\
\hline HBV DNA+ [n (\%)] & $8(100)$ & $42(48.8)$ & $5 / 9(55.5)$ & $3 / 8(37.5)$ & $0(0)$ & $6(46.1)$ & $1(50)$ & $1(100)$ \\
\hline \multicolumn{9}{|l|}{ Genotype [n (\%)] } \\
\hline A & $5(62.5)$ & $24(57.1)$ & $3(60)$ & - & - & $5(83.3)$ & $1(100)$ & $1(100)$ \\
\hline B & - & - & - & $1(33.3)$ & - & - & - & - \\
\hline $\mathrm{D}$ & $3(37.5)$ & $12(28.6)$ & $2(40)$ & $2(66.7)$ & - & $1(16.7)$ & - & - \\
\hline $\mathrm{F}$ & - & $6(14.3)$ & - & - & - & - & - & - \\
\hline Mean of viral load $(\mathrm{cp} / \mathrm{mL})^{a}$ & $7.9 \times 10^{7}$ & $1.7 \times 10^{8}$ & $1 \times 10^{5}$ & $9.2 \times 10^{4}$ & - & $1.5 \times 10^{4}$ & $4.1 \times 10^{7}$ & $7 \times 10^{3}$ \\
\hline \multicolumn{9}{|c|}{ Treatment time (months) } \\
\hline Mean & $9.7 \pm 7.7$ & $21.2 \pm 21$ & $12.7 \pm 3.1^{b}$ & $16.5 \pm 5.3^{b}$ & $12^{b}$ & $8 \pm 5$ & 6 & 12 \\
\hline Median & 6 & 12 & 12 & 12 & 12 & 6 & 6 & 12 \\
\hline
\end{tabular}

$a$ : considering only HBV DNA positive samples; $b$ : mean time of drug addition; ADV: adefovir; ALT: alanine aminotransferase; ETV: entecavir; IFN- $\alpha$ : interferon-alpha; LAM: lamivudine; TDF: tenofovir. 
isolates were found in HBV DNA positive patients undergoing LAM monotherapy $(20 / 41 ; 48.8 \%)$ and LAM combined therapy $(7 / 9 ; 78 \%)$. There was no statistically significant association between the presence or the absence of LAM-resistance mutations and HBV genotypes, $\mathrm{VL}, \mathrm{HBeAg}$ status, ALT levels or duration of the treatment (Table III). However, the type of mutation in the YMDD domain was related to the HBV genotype. The rtM204V mutation was present in 12 out of 13 genotype A isolates, while genotype D isolates showed similar frequencies of the rtM204V and rtM204I variations ( $p$ $=0.023$ ). The type of mutation was also associated with the number of LAM-resistance mutations. Single mutation (rtM204V/I) occurred exclusively in five of nine YIDD variants, while double ( $\mathrm{rtL} 180 \mathrm{M}, \mathrm{rtM} 204 \mathrm{~V} / \mathrm{I})$ or triple (rtV173L, rtL180M, rtM204V/I) mutations occurred in all 18 YVDD variants $(p=0.002)$ (Figure, Table IV). Out of the nine isolates with the rtM204I mutation, six belonged to genotype $\mathrm{D}$ and about half of them displayed a single mutation. Genotype D isolates with the rtM204V variant preferentially displayed a triple mutation, while the genotype A isolates displayed a double mutation $(p=0.04)$.

Besides the main LAM-resistance mutations (rtM204V/I and its compensatory mutations, rtL180M and $\mathrm{rtV173L}$ ), three genotype $\mathrm{D}$ and one genotype $\mathrm{F}$ isolate with the rtM204I mutation also had the substitution mutation, rtL80I. The mutations localised in the rt-A domain (rtS53N and rtT54Y) were commonly associated with the selection for the rtL80I mutants and these mutations were found in six and four YIDD variants, respectively (Figure).

\section{DISCUSSION}

This cross-sectional study is representative of the antiviral therapy used in Brazil for the treatment of chronic hepatitis B. Despite the large number of studies worldwide addressing the different therapeutic strategies and their clinical and virological consequences, only a few studies reporting the situation of antiviral treatment in Brazil are available; however, most of these studies have described the occurrence of LAM-resistance mutations (Da Silva et al. 2001, Bottecchia et al. 2008a, b, Haddad et al. 2010), particularly in HIV/HBV co-infected patients (Santos et al. 2004, Sucupira et al. 2006, Pessoa et al. 2008, Mendes-Correa et al. 2010, Silva et al. 2010). Recent studies, concerning the genotypes endemic in Asia and Europe, have shown that the genotypic profile may play a role in a number of factors, including the emergence of mutations, the severity of liver disease, clinical outcome and response to antiviral therapies (Orito

TABLE III

Frequency of lamivudine (LAM)-resistance mutations in hepatitis B virus DNA positive samples from patients undergoing LAM monotherapy or combined therapy

\begin{tabular}{|c|c|c|c|c|}
\hline & Total & LAM-resistance mutations & Without LAM-resistance mutations & $\mathrm{p}$ \\
\hline Patients [n (\%)] & 50 & $27 / 50(54)$ & $23 / 50(46)$ & - \\
\hline \multicolumn{5}{|c|}{ Type of therapy [n (\%)] } \\
\hline Monotherapy & $41 / 50(82)$ & 20/41 (48.8) & $21 / 41(51.2)$ & - \\
\hline Combination & $9 / 50(18)$ & 7/9 (77.8) & 2/9 (22.2) & - \\
\hline \multicolumn{5}{|l|}{ Genotype [n (\%)] } \\
\hline A & $27 / 50(54)$ & $13 / 27(48.1)$ & $14 / 23(60.9)$ & $0.189^{a}$ \\
\hline B & $1 / 50(2)$ & - & $1 / 23(4.3)$ & - \\
\hline $\mathrm{D}$ & $16 / 50(32)$ & $11 / 27(40.7)$ & $5 / 23(21.7)$ & - \\
\hline $\mathrm{F}$ & $6 / 50(12)$ & 3/27 (11.1) & $3 / 23(13.1)$ & - \\
\hline \multicolumn{5}{|l|}{ Viral load } \\
\hline$<10^{5}[\mathrm{n}(\%)]$ & $26 / 50(52)$ & $12 / 27(44.4)$ & $14 / 23(60.9)$ & 0.39 \\
\hline$>10^{5}[\mathrm{n}(\%)]$ & $24 / 50(48)$ & 15/27 (55.6) & 9/23 (39.1) & - \\
\hline Mean & $1.2 \times 10^{8}$ & $1.2 \times 10^{8}$ & $1.7 \times 10^{8}$ & 0.728 \\
\hline Median & $5.7 \times 10^{4}$ & $1 \times 10^{5}$ & $4.3 \times 10^{4}$ & - \\
\hline \multicolumn{5}{|l|}{$\mathrm{HBeAg}[\mathrm{n}(\%)]$} \\
\hline Negative & $23 / 50(46)$ & 14/27 (51.9) & 9/23 (39.1) & - \\
\hline Positive & $26 / 50(52)$ & $12 / 27(44.4)$ & $14 / 23(60.9)$ & 0.303 \\
\hline Not done & 1/50 (2) & 1/27 (3.7) & - & - \\
\hline \multicolumn{5}{|l|}{ ALT [n (\%)] } \\
\hline Normal & 18/50 (36) & 7/27 (25.9) & $11 / 23(47.8)$ & - \\
\hline Elevated & $30 / 50(60)$ & 18/27 (66.7) & $12 / 23(52.2)$ & 0.156 \\
\hline Not done & 2/50 (4) & 2/27 (7.4) & - & - \\
\hline \multicolumn{5}{|c|}{ Treatment time (months) } \\
\hline Mean & $25.0 \pm 3.9$ & $28.4 \pm 6.4$ & $21 \pm 4.0$ & 0.335 \\
\hline Median & 12 & 12 & 12 & - \\
\hline
\end{tabular}

a: comparison between genotypes A and D; ALT: alanine aminotransferase. 
et al. 2001, Nakayoshi et al. 2003, Kao et al. 2004, Chu \& Liaw 2005, Kramvis \& Kew 2005, Liu \& Kao 2008, Cao 2009). The study of genotypes/subgenotypes, such as genotype $\mathrm{F}$ and subgenotype Al circulating in Brazil, could contribute to the understanding of the role of HBV genotypes on the outcomes of antiviral therapies.

In accordance to previous observations (Gauthier et al. 1999, Mommeja-Marin et al. 2003, Keeffe et al. 2007), this study demonstrated a significant association between elevated ALT levels and positivity of HBV DNA. There was also a significant relationship between HBeAg positive serology and high ALT levels and VLs. Although LAM monotherapy is no longer the first-line choice for treatment against chronic hepatitis B, as postulated in international practice guidelines (Cornberg et al. 2007, Lok \& McMahon 2007), our study showed that LAM was the most common therapy in Brazil until the end of 2009. Indeed, more than $80 \%$ of patients studied were undergoing LAM monotherapy or LAM therapy in combination with another drug. Because LAM has been largely used and LAM combination therapy is effective in patients with LAM resistance, it is probable that the drug will continue to be administered in the future. Earlier studies indicated that IFN- $\alpha$ therapy provided satisfactory results in regards to reduced $\mathrm{VL}$ and $\mathrm{HBeAg}$ seroconversion; they also suggested that rates of HBsAg seroconversion at one year are higher than with therapy with oral agents (Wong et al. 1993, Dienstag et al. 1999, Erhardt et al. 2005, Asselah et al. 2007). In our study, all of the patients treated with IFN- $\alpha$ had detectable levels of HBV DNA and most of them $(7 / 8 ; 87.5 \%)$ were
HBeAg-positive with elevated ALT levels and high VL. This result is in accordance with previous studies that showed that IFN-based therapy is less effective in patients with high-level hepatitis B viremia (Perrillo 1990). These findings are also consistent with lower levels of HBV DNA suppression following IFN- $\alpha$ treatment compared to those following treatment with most oral agents (Dienstag 2008). Previously described differences between HBV genotypes in their responsiveness (i.e., undetectable HBV DNA) to IFN- $\alpha$ therapy (Erhardt et al. 2005) were not observed here.

In this cross-sectional study, a significant difference in LAM therapy compared to newer oral agents like ADV, ETV and TDF in relation to frequency of HBV DNA positivity in patients' serum was not found. However, HBV loads in patients undergoing LAM monotherapy were much higher (3-4 log) than those observed in patients treated with a newer drug or in combination therapy. A recent meta-analysis (Zhao et al. 2011) of previous published articles with chronic hepatitis $B$ patients under TNF treatment showed a decrease of HBV DNA loads to values $<400$ copies $/ \mathrm{mL}$ after 48 weeks of treatment in at least $76 \%$ of the patients. Here, the relatively low rate of HBV DNA suppression by TNF may be due to several factors, including a higher sensitivity in HBV DNA detection, characteristics of the HBV isolates and characteristics of the population under analysis.

In the sequenced genomic region $\mathrm{rt}$ domain 1-230 overlapping the pre-S/S region), no mutations other than those for LAM resistance have been found. However, the major resistance mutation to ADV is found

\begin{tabular}{|c|c|c|c|c|c|c|c|}
\hline HBV Wi & ld Type & $\begin{array}{l}50 \\
\text { SRGSTRVSWP }\end{array}$ & ${ }^{80}$ LSLDVSAAFY & ${ }^{170}$ PMGVGLSPFL & LAQFTSAICS & VVRRAFPHCL & $\begin{array}{lr}0 & 210 \\
\text { AFSYMDDVVI }\end{array}$ \\
\hline NN006 & (A) & $\ldots I \ldots$. & $\cdots \cdots \cdots$ & $\ldots \ldots \ldots$ & M....... & $\cdots \cdots \cdots$ & $\ldots v \ldots$. \\
\hline NN007 & (A) & $\ldots$ I.... & $\ldots \ldots \ldots$ & $\ldots \ldots \ldots$ & M....... & $\ldots \ldots \ldots$ & ...V. I. . \\
\hline NN009 & (A) & $\ldots$ I..... & $\ldots \ldots \ldots$ & $\ldots \ldots \ldots$ & M....... & $\ldots \ldots \ldots$ & $\ldots v \ldots$ \\
\hline NN010 & (A) & $\ldots v \ldots$. & $\ldots \ldots \ldots$ & $\ldots \ldots$ & $\ldots \ldots \ldots$ & $\ldots \ldots \ldots$ & $\ldots I \ldots$ \\
\hline NN018 & (A) & $\ldots \ldots \ldots$ & $\ldots \ldots \ldots$ & $\ldots \ldots \ldots$ & $M \ldots \ldots$ & $\cdots \cdots \cdots$ & $\ldots v \ldots$. \\
\hline NNO24 & (A) & $\ldots$ I..... & $\ldots \ldots \ldots$ & $\ldots \ldots \ldots$ & M. . . . . & $\ldots \ldots \ldots$ & $\ldots v \ldots$ \\
\hline NN026 & (A) & $\ldots I \ldots \ldots$ & $\ldots \ldots \ldots$ & $\ldots \ldots \ldots$ & M. . . R R & $\cdots \cdots \cdots$ & .s..V.... \\
\hline NN028 & (A) & $\ldots$ I . . . & $\ldots \ldots \ldots$ & $\ldots$ L. . . . & M....... & $\ldots \ldots \ldots$ & $\ldots v \ldots$. \\
\hline NN032 & (A) & $\ldots$ I $\ldots \ldots$ & $\ldots \ldots \ldots$ & $\ldots \ldots \ldots$ & M...... & $\ldots \ldots \ldots$ & $\ldots v \ldots$ \\
\hline NN042 & (A) & $\ldots I \ldots \ldots$ & $\cdots \cdots \cdots$ & $\ldots \ldots \ldots$ & M....... & $\ldots \ldots \ldots$ & $\ldots v \ldots$ \\
\hline NN080 & (A) & $\ldots v \ldots$. & $\cdots \cdots \cdots$ & $\ldots \ldots \ldots$ & MT ...... & $\cdots \cdots \cdots$ & $\ldots v \ldots$ \\
\hline NN124 & (A) & $\ldots$ I . . . & $\ldots \ldots \ldots$ & $\ldots \ldots \ldots$ & M. . . . . . & $\ldots \ldots \ldots$ & $\ldots v \ldots$ \\
\hline NN132 & (A) & $\ldots I \ldots \ldots$ & $\ldots \ldots \ldots$ & $\ldots \ldots \ldots$ & M........ & $\ldots \ldots \ldots$ & $\ldots v \ldots$ \\
\hline NN001 & (D) & $\ldots N Y \ldots$ & $\cdots \cdots \cdots$ & $\ldots$ L..... & M........ & $\cdots \cdots \cdots$ & $\ldots V \ldots$ \\
\hline NN015 & (D) & $\ldots N Y \ldots$ & $\cdots \cdots \cdots$ & $\cdots \cdots \cdots$ & $\cdots \cdots \cdots$ & $\ldots \ldots$ & $\ldots$ I.... \\
\hline NN031 & (D) & $\ldots$ NY . . . . & $\ldots \ldots \ldots$ & $\ldots$ L . . . . & M....... & $\ldots \ldots \ldots$ & $\ldots v \ldots$ \\
\hline NN034 & (D) & $\ldots N Y \ldots$. & $\ldots \ldots \ldots$ & $\ldots$ L..... & M. . . . . . & $\ldots \ldots \ldots$ & $\ldots v \ldots$ \\
\hline NN074 & (D) & $\ldots N Y \ldots$ & $I \ldots \ldots$ & $\cdots \cdots \cdots$ & M........ & $\cdots \cdots \cdots$ & $\ldots V \ldots$ \\
\hline NN077 & (D) & $\ldots$ NY .... & I $\ldots \ldots$ & $\ldots$ L..... & M........ & $\cdots \cdots \cdots$ & $\ldots$ I.... \\
\hline NN084 & (D) & $\ldots N Y \ldots$ & I $\ldots \ldots \ldots$ & $\ldots \ldots \ldots$ & $\ldots \ldots \ldots$ & $\ldots \ldots \ldots$ & $\ldots$ I.... \\
\hline NN088 & (D) & $\ldots$ NY .... & $\ldots \ldots \ldots$ & $\ldots \ldots \ldots$ & M........ & $\ldots \ldots \ldots$ & $\ldots$ I.... \\
\hline NN091 & (D) & $\ldots$ NH $\ldots$. & $\ldots \ldots$ & $\ldots \ldots$ & $\cdots \cdots$ & $\ldots \ldots \ldots$ & $\ldots$ I $\ldots$ \\
\hline $\mathrm{NN} 125$ & (D) & $\ldots$ NY ..... & I $\ldots \ldots$ & $\ldots \ldots \ldots$ & M....... & $\ldots \ldots \ldots$ & $\ldots$ I.... \\
\hline NN129 & (D) & $\ldots$ NY $\ldots$ & $\cdots \cdots \cdots$ & $\ldots$ L $\ldots$. & M...... & $\cdots \cdots \cdots$ & $\ldots v \ldots$ \\
\hline NN105 & $(F)$ & $\ldots$ T.... & $\ldots \ldots \ldots$ & $\ldots \ldots \ldots$ & M....... & $\ldots \ldots \ldots$ & ...V... L \\
\hline NN126 & (F) & $\ldots$ N..... & $\ldots \ldots \ldots$ & $\ldots \ldots$ & M....... & $\ldots \ldots \ldots$ & ...I.I. . \\
\hline NN134 & $(\mathrm{F})$ & $\ldots$ т..... & I $\ldots \ldots$ & $\ldots \ldots \ldots$ & M........ & & ...I.I. . \\
\hline
\end{tabular}

Amino acid substitutions in the reverse transcriptase domain of polymerase of hepatitis B virus (HBV) isolates with lamivudine-resistance mutations. HBV genotypes are written in brackets. 
at residue rt236. The four samples of patients under ADV were further submitted to nucleotide sequencing to highlight this point. No additional mutations were found (not shown). Nearly half of the patients undergoing LAM monotherapy had LAM-resistant isolates and an even higher frequency $(77.8 \%)$ was found among patients undergoing a combination therapy of LAM with other oral agents, suggesting that the addition of a second drug was a rescue therapy (Table III). Although combination therapies were unable to revert LAM-resistance mutations, they played a major role in reducing VL (Table II). The high rate of LAM resistance observed here could limit the chance of a successful treatment with ETV or LdT due to cross-resistance between these drugs.

The distribution of HBV genotypes confirmed the previous studies where the higher prevalence of genotype A, followed by genotype D and F, was reported (Moraes et al. 1996, Teles et al. 2002, Araujo et al. 2004, Sitnik et al. 2004, Mello et al. 2007). The unequal distribution of genotypes A and D between the southeastern and southern regions of Brazil was also confirmed. Unlike the other states from the southeastern region, ES, where high endemic areas for HBV infection are found, had an equal distribution of genotype A and D. Due to the irregular distribution of the eight known HBV genotypes and many subgenotypes around the world, there are still major gaps in the understanding of how the HBV genotype may influence the course of disease and the response to antiviral treatment. Most clinical data were obtained in Asia, where genotypes $\mathrm{B}$ and $\mathrm{C}$ co-circulate with high prevalence of infection (Orito et al. 2006). Large-scale studies with genotypes A and D, predominant in Europe and South America and frequently found in Africa, are necessary to increase our understanding of the features of the HBV genotypes/subgenotypes. To our knowledge, the present study was conducted with the highest number of hepatitis B Brazilian patients undergoing treatment. Previous studies performed in Europe have suggested that the rate of LAM resistance was higher in patients infected with the HBV genotype A than with genotype D (Zollner et al. 2001, 2004). Here, no statistically significant correlation was found between the occurrence of LAM-resistant mutations and infection with a determined genotype (A vs. $\mathrm{D} ; \mathrm{p}=0.189$ ). Whether the differences found between Europe and Brazil are due to variations in the distribution of HBV A and D subgenotypes requires further investigation. In addition, $\mathrm{HBeAg}$ negativity may be associated with a lower rate of emergence of HBV polymerase mutants during LAM treatment (Lau et al. 2000, Nafa et al. 2000). In the current study, no relationship between HBeAg status and the frequency of LAM resistance mutations was observed.

Previous studies have shown that there is a difference in the pattern of YMDD mutants between the major HBV genotypes (Zollner et al. 2004, Svicher et al. 2009, Damerow et al. 2010). Our results confirmed those findings, as a significant association between the occurrence of the rtM204V mutation in genotype A and the rtM204I in genotypes $\mathrm{D}$ and $\mathrm{F}$ was observed. In accordance with the extensive literature review by Damerow et al. (2010), our findings indicated that the rtM204I mutation preferentially appears alone, while the rtM204V mutation always appears together with rtL180M or rtL180M and rtV173L. Here, six (22.2\%) isolates displayed LAM triple mutations that are known to result in aa changes $(\mathrm{sE164D}+\mathrm{sI195M})$ in the overlapping surface gene. These mutations strongly reduce the binding affinity with anti-HBs to levels similar to the vaccine escape mutant sG145R (Sheldon \& Soriano 2008). This finding could represent a serious epidemiology issue if these isolates begin to circulate in the environment. Interestingly, genotype D isolates with the rtM204V variant preferentially displayed a triple mutation, while genotype A preferentially displayed a double mutation. Of the nine rtM204I mutants, four (44.4\%) were associated with the rtL80I mutation in the RT-A domain, which has been shown to enhance the replication ability of HBV in the YIDD variants (Warner et al. 2007, Svicher et al. 2009).

TABLE IV

Differences between hepatitis B virus genotypes, YMDD variants and number of lamivudine (LAM)-resistance mutations in patients undergoing LAM monotherapy or combined therapy

\begin{tabular}{|c|c|c|c|c|}
\hline \multirow[b]{2}{*}{ Patients (n) } & \multirow{2}{*}{$\begin{array}{c}\text { Frequency of LAM-mutations } \\
27\end{array}$} & \multicolumn{2}{|c|}{ YMDD variant } & \multirow{2}{*}{ p } \\
\hline & & rtM204V & rtM204I & \\
\hline \multicolumn{5}{|c|}{ Genotype [n (\%)] } \\
\hline$A(n=27)$ & $13(48.1)$ & $12(92.3)$ & $1(7.7)$ & $0.023^{a}$ \\
\hline $\mathrm{B}(\mathrm{n}=1)$ & $0(0)$ & - & - & - \\
\hline$D(n=16)$ & $11(68.8)$ & $5(45.4)$ & $6(54.6)$ & - \\
\hline$F(n=6)$ & $3(50)$ & $1(33.3)$ & $2(66.7)$ & - \\
\hline \multicolumn{5}{|c|}{ LAM mutations [n (\%)] } \\
\hline Single ${ }^{b}$ & $5(18.6)$ & $0(0)$ & $5(100)$ & - \\
\hline Double ${ }^{c}$ & $16(59.2)$ & $13(81.2)$ & $3(18.8)$ & 0.002 \\
\hline Triple $^{d}$ & $6(22.2)$ & $5(83.3)$ & $1(16.7)$ & - \\
\hline
\end{tabular}

$a$ : comparison between genotypes A and D for the presence of YMDD variant rtM204V or rtM204I; $b$ : rtM204V/I; $c$ : rtL180M, $\mathrm{rtM} 204 \mathrm{~V} / \mathrm{I} ; d: \mathrm{rtV} 173 \mathrm{~L}, \mathrm{rtL} 180 \mathrm{M}, \mathrm{rtM} 204 \mathrm{~V} / \mathrm{I}$. 
These isolates (except 1 from genotype F) also had substitutions in residues rt53 and rt54 that, as suggested by Svicher et al. (2009), could act as genetic determinants in the selection of the rtL80I mutation by stabilising the secondary structure of the RT-A domain.

In conclusion, the present study reported an overview of the current status of antiviral therapy against chronic hepatitis B in Brazil. Additionally, this study evaluated the frequency of HBV DNA positivity and LAM resistance mutations in different therapies. A difference in the pattern of YMDD variants among the major HBV genotypes circulating in Brazil was found. YVDD variants were found in 12/13 (92\%) genotype A isolates, while the YIDD variation was found more frequently in genotypes $\mathrm{D}(6 / 11 ; 54 \%)$ and $\mathrm{F},(2 / 3 ; 67 \%)$. The number of mutations was also associated with the genotype, as the YMDD triple mutation was more common in genotype $\mathrm{D}$, while the majority of genotype A isolates had a YMDD double mutation. Further studies with a larger sample and/or with a longitudinal approach are needed to confirm whether these differences in mutational patterns may interfere and/or modify the efficiency of the newer drugs when used as monotherapy or in combination.

\section{ACKNOWLEDGEMENTS}

To the Plataforma Genômica - Seqüenciamento de DNA/ PDTIS-FIOCRUZ, for performing the DNA sequencing.

\section{REFERENCES}

Araujo NM, Mello FC, Yoshida CF, Niel C, Gomes SA 2004. High proportion of subgroup A' (genotype A) among Brazilian isolates of hepatitis B virus. Arch Virol 149: 1383-1395.

Asselah T, Lada O, Moucari R, Martinot M, Boyer N, Marcellin P 2007. Interferon therapy for chronic hepatitis B. Clin Liver Dis 11: 839-849.

Bhattacharya D, Thio CL 2010. Review of hepatitis B therapeutics. Clin Infect Dis 51: 1201-1208.

Bottecchia M, Ikuta N, Niel C, Araujo NM, O Kycia MR, Gomes SA 2008a. Lamivudine resistance and other mutations in the polymerase and surface antigen genes of hepatitis $\mathrm{B}$ virus associated with a fatal hepatic failure case. $J$ Gastroenterol Hepatol 23: 67-72.

Bottecchia M, Souto FJ, O Kycia MR, Amendola M, Brandao CE, Niel C, Gomes SA 2008b. Hepatitis B virus genotypes and resistance mutations in patients under long term lamivudine therapy: characterization of genotype G in Brazil. BMC Microbiol 8: 11.

Cao GW 2009. Clinical relevance and public health significance of hepatitis B virus genomic variations. World J Gastroenterol 15: 5761-5769.

Chu CM, Liaw YF 2005. Genotype C hepatitis B virus infection is associated with a higher risk of reactivation of hepatitis B and progression to cirrhosis than genotype B: a longitudinal study of hepatitis B e antigen-positive patients with normal aminotransferase levels at baseline. J Hepatol 43: 411-417.

Cornberg M, Protzer U, Dollinger MM, Petersen J, Wedemeyer H, Berg T, Jilg W, Erhardt A, Wirth S, Schirmacher P, Fleig WE, Manns MP 2007. Prophylaxis, diagnosis and therapy of hepatitis $B$ virus (HBV) infection: the German guidelines for the management of HBV infection. Z Gastroenterol 45: 1281-1328.

Da Silva LC, Pinho JR, Sitnik R, Da Fonseca LE, Carrilho FJ 2001. Efficacy and tolerability of long-term therapy using high lamivudine doses for the treatment of chronic hepatitis B. J Gastroenterol 36: 476-485.
Damerow H, Yuen L, Wiegand J, Walker C, Bock CT, Locarnini S, Tillmann HL 2010. Mutation pattern of lamivudine resistance in relation to hepatitis B genotypes: hepatitis B genotypes differ in their lamivudine resistance associated mutation pattern. $J$ Med Virol 82: 1850-1858.

Delaney WET, Borroto-Esoda K 2008. Therapy of chronic hepatitis B: trends and developments. Curr Opin Pharmacol 8: 532-540.

Dienstag JL 2008. Hepatitis B virus infection. N Engl J Med 359: 1486-1500.

Dienstag JL, Schiff ER, Wright TL, Perrillo RP, Hann HW, Goodman Z, Crowther L, Condreay LD, Woessner M, Rubin M, Brown NA 1999. Lamivudine as initial treatment for chronic hepatitis B in the United States. N Engl J Med 341: 1256-1263.

Enomoto M, Tamori A, Kohmoto MT, Morikawa H, Habu D, Sakaguchi H, Takeda T, Seki S, Kawada N, Shiomi S, Nishiguchi S 2007. Mutational patterns of hepatitis B virus genome and clinical outcomes after emergence of drug-resistant variants during lamivudine therapy: analyses of the polymerase gene and fulllength sequences. J Med Virol 79: 1664-1670.

Erhardt A, Blondin D, Hauck K, Sagir A, Kohnle T, Heintges T, Haussinger D 2005. Response to interferon alfa is hepatitis B virus genotype dependent: genotype A is more sensitive to interferon than genotype D. Gut 54: 1009-1013.

Gauthier J, Bourne EJ, Lutz MW, Crowther LM, Dienstag JL, Brown NA, Condreay LD 1999. Quantitation of hepatitis B viremia and emergence of YMDD variants in patients with chronic hepatitis B treated with lamivudine. J Infect Dis 180: 1757-1762.

Haddad R, Martinelli Ade L, Uyemura SA, Yokosawa J 2010. Hepatitis B virus genotyping among chronic hepatitis B patients with resistance to treatment with lamivudine in the city of Ribeirão Preto, state of São Paulo. Rev Soc Bras Med Trop 43: 224-228.

Hadziyannis SJ, Tassopoulos NC, Heathcote EJ, Chang TT, Kitis G, Rizzetto M, Marcellin P, Lim SG, Goodman Z, Ma J, Brosgart CL, Borroto-Esoda K, Arterburn S, Chuck SL 2006. Long-term therapy with adefovir dipivoxil for HBeAg-negative chronic hepatitis B for up to 5 years. Gastroenterology 131: 1743-1751.

Kao JH, Chen PJ, Lai MY, Chen DS 2004. Hepatitis B virus genotypes and spontaneous hepatitis $\mathrm{B}$ e antigen seroconversion in Taiwanese hepatitis B carriers. J Med Virol 72: 363-369.

Keeffe EB, Zeuzem S, Koff RS, Dieterich DT, Esteban-Mur R, Gane EJ, Jacobson IM, Lim SG, Naoumov N, Marcellin P, Piratvisuth T, Zoulim F 2007. Report of an international workshop: roadmap for management of patients receiving oral therapy for chronic hepatitis B. Clin Gastroenterol Hepatol 5: 890-897.

Kramvis A, Kew MC 2005. Relationship of genotypes of hepatitis B virus to mutations, disease progression and response to antiviral therapy. J Viral Hepat 12: 456-464.

Lai CL, Dienstag J, Schiff E, Leung NW, Atkins M, Hunt C, Brown N, Woessner M, Boehme R, Condreay L 2003. Prevalence and clinical correlates of YMDD variants during lamivudine therapy for patients with chronic hepatitis B. Clin Infect Dis 36: 687-696.

Lau DT, Khokhar MF, Doo E, Ghany MG, Herion D, Park Y, Kleiner DE, Schmid P, Condreay LD, Gauthier J, Kuhns MC, Liang TJ, Hoofnagle JH 2000. Long-term therapy of chronic hepatitis B with lamivudine. Hepatology 32: 828-834.

Liu CJ, Kao JH 2008. Genetic variability of hepatitis B virus and response to antiviral therapy. Antivir Ther 13: 613-624.

Lok AS, McMahon BJ 2007. Chronic hepatitis B. Hepatology 45: 507-539.

Mello FC, Souto FJ, Nabuco LC, Villela-Nogueira CA, Coelho HS, Franz HC, Saraiva JC, Virgolino HA, Motta-Castro AR, Melo 
MM, Martins RM, Gomes SA 2007. Hepatitis B virus genotypes circulating in Brazil: molecular characterization of genotype $\mathrm{F}$ isolates. BMC Microbiol 7: 103.

Mendes-Correa MC, Pinho JR, Locarnini S, Yuen L, Sitnik R, Santana RA, Gomes-Gouvea MS, Leite OM, Martins LG, Silva MH, Gianini RJ, Uip DE 2010. High frequency of lamivudine resistance mutations in Brazilian patients co-infected with HIV and hepatitis B. J Med Virol 82: 1481-1488.

Mommeja-Marin H, Mondou E, Blum MR, Rousseau F 2003. Serum HBV DNA as a marker of efficacy during therapy for chronic HBV infection: analysis and review of the literature. Hepatology 37: 1309-1319.

Moraes MT, Gomes SA, Niel C 1996. Sequence analysis of pre-S/S gene of hepatitis B virus strains of genotypes A, D and F isolated in Brazil. Arch Virol 141: 1767-1773.

Moraes MT, Niel C, Gomes SA 1999. A polymerase chain reactionbased assay to identify genotype $\mathrm{F}$ of hepatitis B virus. Braz J Med Biol Res 32: 45-49.

MS - Ministério da Saúde 2010. [homepage on the Internet]. Protocolo clínico e diretrizes terapêuticas para o tratamento da hepatite viral crônica B e co-infecções. Available from: portal.saude.gov.br/ portal/arquivos/pdf/protocolo_hepatites.pdf.

Nafa S, Ahmed S, Tavan D, Pichoud C, Berby F, Stuyver L, Johnson M, Merle P, Abidi H, Trepo C, Zoulim F 2000. Early detection of viral resistance by determination of hepatitis B virus polymerase mutations in patients treated by lamivudine for chronic hepatitis B. Hepatology 32: 1078-1088.

Nakayoshi T, Maeshiro T, Nakasone H, Sakugawa H, Kinjo F, Orito E, Mizokami M 2003. Difference in prognosis between patients infected with hepatitis B virus with genotype B and those with genotype $\mathrm{C}$ in the Okinawa Islands: a prospective study. $\mathrm{J} \mathrm{Med}$ Virol 70: 350-354.

Orito E, Fujiwara K, Tanaka Y, Yuen MF, Lai CL, Kato T, Sugauchi F, Kusakabe A, Sata M, Okanoue T, Niitsuma H, Sakugawa H, Hasegawa I, Mizokami M 2006. A case-control study of response to lamivudine therapy for 2 years in Japanese and Chinese patients chronically infected with hepatitis B virus of genotypes $\mathrm{Bj}$, Ba and C. Hepatol Res 35: 127-134.

Orito E, Mizokami M, Sakugawa H, Michitaka K, Ishikawa K, Ichida T, Okanoue T, Yotsuyanagi H, Iino S 2001. A case-control study for clinical and molecular biological differences between hepatitis B viruses of genotypes B and C. Japan HBV Genotype Research Group. Hepatology 33: 218-223.

Pas SD, Niesters HG 2002. Detection of HBV DNA using real time analysis. J Clin Virol 25: 93-94.

Perrillo RP 1990. Factors influencing response to interferon in chronic hepatitis B: implications for Asian and western populations. Hepatology 12: 1433-1435.

Pessoa MG, Gazzard B, Huang AK, Brandao-Mello CE, Cassetti I, Mendes-Correa MC, Soriano V, Phiri P, Hall A, Brett-Smith H 2008. Efficacy and safety of entecavir for chronic HBV in HIV/ HBV coinfected patients receiving lamivudine as part of antiretroviral therapy. AIDS 22: 1779-1787.

Santos EA, Sucupira MV, Arabe J, Gomes SA 2004. Hepatitis B virus variants in an HIV-HBV co-infected patient at different periods of antiretroviral treatment with and without lamivudine. $B M C$ Infect Dis 4: 29.

Sheldon J, Soriano V 2008. Hepatitis B virus escape mutants induced by antiviral therapy. J Antimicrob Chemother 61: 766-768.
Silva AC, Spina AMM, Lemos MF, Oba IT, Guastini CF, GomesGouvea MS, Pinho JRR, Mendes-Correa MCJ 2010. Hepatitis B genotype $\mathrm{G}$ and high frequency of lamivudine-resistance mutations among human immunodeficiency virus/hepatitis B virus coinfected patients in Brazil. Mem Inst Oswaldo Cruz 105: 770-778.

Sitnik R, Pinho JR, Bertolini DA, Bernardini AP, Da Silva LC, Carrilho FJ 2004. Hepatitis B virus genotypes and precore and core mutants in Brazilian patients. J Clin Microbiol 42: 2455-2460.

Sucupira MVF, Mello FCA, Santos EA, Niel C, Rolla VC, Arabe J, Gomes SA 2006. Patterns of hepatitis B virus infection in Brazilian human immunodeficiency virus infected patients: high prevalence of occult infection and low frequency of lamivudine resistant mutations. Mem Inst Oswaldo Cruz 101: 655-660.

Svicher V, Gori C, Trignetti M, Visca M, Micheli V, Bernassola M, Salpini R, Gubertini G, Longo R, Niero F, Ceccherini-Silberstein F, De Sanctis GM, Spano A, Cappiello G, Perno CF 2009. The profile of mutational clusters associated with lamivudine resistance can be constrained by HBV genotypes. J Hepatol 50: 461-470.

Tamura K, Dudley J, Nei M, Kumar S 2007. MEGA4: Molecular Evolutionary Genetics Analysis (MEGA) software version 4.0. Mol Biol Evol 24: 1596-1599.

Teles SA, Martins RM, Gomes SA, Gaspar AM, Araujo NM, Souza KP, Carneiro MA, Yoshida CF 2002. Hepatitis B virus transmission in Brazilian hemodialysis units: serological and molecular follow-up. J Med Virol 68: 41-49.

Thompson JD, Higgins DG, Gibson TJ 1994. CLUSTALW: improving the sensitivity of progressive multiple sequence alignment through sequence weighting, position-specific gap penalties and weight matrix choice. Nucleic Acids Res 22: 4673-4680.

Warner N, Locarnini S, Kuiper M, Bartholomeusz A, Ayres A, Yuen $\mathrm{L}$, Shaw T 2007. The L80I substitution in the reverse transcriptase domain of the hepatitis B virus polymerase is associated with lamivudine resistance and enhanced viral replication in vitro. Antimicrob Agents Chemother 51: 2285-2292.

WHO - World Health Organization 2008. [homepage on the Internet]. Hepatitis B [revised 2008 August; cited 2011 april 5]. Available from: who.int/mediacentre/factsheets/fs204/en/.

Wiegand J, van Bömmel F, Berg T 2010. Management of chronic hepatitis B: status and challenges beyond treatment guidelines. Semin Liver Dis 30: 361-377.

Wong DK, Cheung AM, O'Rourke K, Naylor CD, Detsky AS, Heathcote J 1993. Effect of alpha-interferon treatment in patients with hepatitis B e antigen-positive chronic hepatitis B. A meta-analysis. Ann Intern Med 119: 312-323.

Yuen LK, Locarnini SA 2009. Genetic variability of hepatitis B virus and response to antiviral treatments: searching for a bigger picture. J Hepatol 50: 445-448.

Zhao SS, Tang LH, Dai XH, Wang W, Zhou RR, Chen LZ, Fan XG 2011. Comparison of the efficacy of tenofovir and adefovir in the treatment of chronic hepatitis B: a systematic review. Virol J 8: 111.

Zollner B, Petersen J, Puchhammer-Stockl E, Kletzmayr J, Sterneck M, Fischer L, Schroter M, Laufs R, Feucht HH 2004. Viral features of lamivudine resistant hepatitis B genotypes A and D. Hepatology 39: 42-50.

Zollner B, Petersen J, Schroter M, Laufs R, Schoder V, Feucht HH 2001. 20 -fold increase in risk of lamivudine resistance in hepatitis B virus subtype adw. Lancet 357: 934-935.

Zoulim F, Locarnini S 2009. Hepatitis B virus resistance to nucleos(t) ide analogues. Gastroenterology 137: 1593-1608. 